\title{
ICE-CORING AT MIZUHO STATION, ANTARCTICA, AND CORE ANALYSES: A CONTRIBUTION FROM THE GLACIOLOGICAL RESEARCH PROGRAM IN EAST DRONNING MAUD LAND, ANTARCTICA
}

\author{
by \\ H. Narita \\ (Institute of Low Temperature Science, Hokkaido University, Sapporo 060, Japan)
}

S. Mae and M. Nakawo

(Department of Applied Physics, Faculty of Engineering, Hokkaido University, Sapporo 060, Japan)

Y. Fujii and M. Yoshida

(National Institute of Polar Research, 9-10, 1-chome, Kaga, Itabashi-ku, Tokyo 173, Japan)

K. Kawada

(Department of Physics, Toyama University, 3190 Gofuku, Toyama 930, Japan)

and

A. Higashi

(Division of Natural Sciences, International Christian University, 10-2, Osawa 3-chome, Mitaki-shi, Tokyo 181, Japan)

\begin{abstract}
Between May 1983 and July 1984 glaciological parties of the 24th and 25th Japanese Antarctic Research Expeditions (JARE-24 and 25) carried out ice-core drilling using a thermal drill, down to $700.5 \mathrm{~m}$ depth at Mizuho Station $\left(70^{\circ} 41^{\prime} 53^{\prime \prime} \mathrm{S}, \quad 44^{\circ} 19^{\prime} 54^{\prime \prime} \mathrm{E}\right)$, as a part of the Glaciological Research Program in east Dronning Maud Land, Antarctica.

The thermal drill, $3.9 \mathrm{~m}$ long and capable of taking a core $1.5 \mathrm{~m}$ long and $130 \mathrm{~mm}$ in diameter, is an improved version of a drill used by JARE-15 in 1975. The most important improvement was the monitoring system during drilling, for which a micro-computer was fitted in the drill. By using this system, such accidents as heater burn-out, tank overflow and failure of water suction would immediately be brought to our attention. The drilling speed was about $1.6 \mathrm{~m} / \mathrm{h}$, when the optimum output was $3.6 \mathrm{~kW}$. The core recovery rate was above $99 \%$.

The core quality was good down to a depth of $80 \mathrm{~m}$. Between 80 and $120 \mathrm{~m}$, cracks were found at intervals
\end{abstract}

of $0.15-0.5 \mathrm{~m}$, and horizontal cracks were found continuously at intervals of $0.01 \mathrm{~m}$ or less.

Immediately after the core was pulled, the stratigraphy was observed and bulk density was measured. A dust band, presumably volcanic particles, was seen at only $500.2 \mathrm{~m}$ depth during stratigraphic observation. The following analyses were carried out at Mizuho Station within a month of recovery:

(1) Density determination by the hydrostatic method.

(2) Measurement of total gas content.

(3) Thin-section analyses, including observation of cracking around air bubbles and the crystalline texture, and ice-fabric studies.

The $700.5 \mathrm{~m}$ core has been brought to Japan, and the following analyses are now under way:

(1) Oxygen-isotope ratio.

(2) Concentration of microparticles.

(3) Electric conductivity.

(4) Chemistry of soluble impurities. 